\title{
25. STRONTIUM-ISOTOPE GEOCHEMISTRY OF CARBONATES FROM PACIFIC GUYOTS ${ }^{1}$
}

\author{
P.A. Wilson, ${ }^{2}$ B.N. Opdyke, ${ }^{3}$ and H. Elderfield ${ }^{2}$
}

\begin{abstract}
${ }^{87} \mathrm{Sr} /{ }^{86} \mathrm{Sr}$ data are presented for shallow-water carbonates plus vein and vesicle carbonate precipitated in basalt from Holes 871C, 872B, 877 A, 878A, and 879A drilled during Leg 144 into Limalok, Lo-En, Wodejebato, MIT, and Tayuko-Daisan guyots, respectively. These data range from 0.70721 to 0.70862 (shallow-water carbonates) and from 0.70361 to 0.70767 (vein and vesicle carbonates) and compare with the range from 0.70720 to 0.70917 for Cretaceous to modern seawater. Notwithstanding the limits of strontium isotope stratigraphy as applied to Cretaceous and Paleocene sequences, these data may support the scenario of a "greenhouse" Cretaceous/Paleocene world in which (1) ocean saturation with respect to $\mathrm{CaCO}_{3}$ was low; (2) atolls drowned as they approached the equator on the northward-moving Pacific Plate; (3) carbonate platforms were permeable to significant seawater circulation and chemical exchange, in some cases until long after guyot formation; and (4) circulation was driven by a geothermal gradient from underlying volcanic pedestals that, in some cases, experienced seawater-basalt interaction on a magnitude hitherto unreported from non-ocean ridge sites.
\end{abstract}

\section{INTRODUCTION}

Legs 143 and 144 of the Ocean Drilling Program (ODP) provided excellent opportunities to study the evolution of drowned shallowwater carbonate platforms and their volcanic pedestals (guyots) in the equatorial Pacific. Leg 144 had 12 major objectives, six of which are relevant to this paper: (1) to date the interface between pelagic cap and the underlying platform, (2) to infer the age and cause of platform drowning, (3) to establish the stratigraphy and growth history of the carbonate platform, (4) to examine the timing and mode of carbonate platform diagenesis, (5) to determine the emergence and subsidence history of platform carbonates relative to sea level, and (6) to obtain geochemical data from the volcanic edifices for comparison with other sites plus the South Pacific Isotopic Thermal Anomaly (SOPITA) and the Dupré-Allegre (DUPAL) isotopic anomaly (Premoli Silva, Haggerty, Rack, et al., 1993, p. 3).

Early attempts at addressing similar problems from drill holes through surviving Pacific atolls (e.g., Major and Matthews, 1983; Lincoln and Schlanger, 1987) were hampered by the difficulty of dating shallow-water carbonates using conventional bio- and magnetostratigraphic methods. Consequently, much effort has been directed toward the development of chemostratigraphic methods for dating these types of sediments. Perhaps the most established of these methods is strontium isotope stratigraphy (Elderfield, 1986).

The oceanic residence time of strontium ( 2 Ma) greatly exceeds the oceanic mixing time $\left(\sim 10^{3} \mathrm{yr}\right)$. Hence, at any one time, the isotopic composition of dissolved strontium in the oceans is uniform. The value of the seawater strontium-isotope ratio has changed over geologic time (Burke et al., 1982) in response to varying proportions of $\mathrm{Sr}$ derived from continental crust $\left({ }^{87} \mathrm{Sr} /{ }^{86} \mathrm{Sr} \approx 0.716\right)$ and the upper mantle $\left({ }^{87} \mathrm{Sr} /{ }^{86} \mathrm{Sr} \approx 0.703\right)$ as buffered by carbonate recycling (Elderfield, 1986). Because biogenic and inorganic marine carbonates record the equilibrium ${ }^{87} \mathrm{Sr} /{ }^{86} \mathrm{Sr}$ of contemporaneous seawater, $\mathrm{Sr}$-isotopes have significant potential for chemostratigraphy and as a

\footnotetext{
${ }^{1}$ Haggerty, J.A., Premoli Silva, I., Rack, F., and McNutt, M.K. (Eds.), 1995. Proc. ODP, Sci. Results, 144: College Station, TX (Ocean Drilling Program).

${ }^{2}$ Department of Earth Sciences, University of Cambridge, Downing Street, Cambridge CB2 3EQ, United Kingdom.

${ }^{3}$ Department of Geological Sciences, University of Michigan, Ann Arbor, MI 48109. U.S.A. (Present address: Department of Geology, Faculty of Science, The Australian National University, Canberra ACT 0200, Australia.)
}

tracer for deciphering the sources, flow paths, and mixing histories of diagenetic fluids.

The success of strontium-isotope stratigraphy relies heavily on (1) the existence of a well-defined, rapid, and monotonically changing ${ }^{87} \mathrm{Sr} /{ }^{86} \mathrm{Sr}$ seawater curve for the appropriate time interval; and (2) the ability to distinguish primary ${ }^{87} \mathrm{Sr} /{ }^{86} \mathrm{Sr}$ values from those resulting from diagenetic alteration.

The seawater ${ }^{87} \mathrm{Sr} /{ }^{86} \mathrm{Sr}$ curve for the Oligocene through Neogene ( $\sim 33-0 \mathrm{Ma})$ as defined from deep ocean cores shows a well-defined, rapid, and monotonic increase (Fig. 1A). This pattern is ideally suited to strontium-isotope stratigraphy (e.g., Burke et al., 1982; DePaolo, 1986; McKenzie et al., 1988, 1993; Miller et al., 1988; Hodell et al., 1991). However, the ${ }^{87} \mathrm{Sr} /{ }^{86} \mathrm{Sr}$ seawater curve for the Cretaceous (as defined from well-dated European sections) is embryonic (Fig. 1B) and appears to show a more complex pattern (Koepnick et al., 1985, 1988; Jones, 1992; Jones et al., 1994; McArthur et al., 1992, 1993a, $1993 \mathrm{~b}, 1994)$. Furthermore, the ${ }^{87} \mathrm{Sr} /{ }^{86} \mathrm{Sr}$ seawater curve for the $\mathrm{Pa}$ leocene through Eocene is very poorly defined and apparently shows little variation (e.g., Hess et al., 1986; Koepnick et al., 1985, 1988; Denison et al., 1993; P.A. Wilson et al., unpubl. data). These complications in the ${ }^{87} \mathrm{Sr} /{ }^{86} \mathrm{Sr}$ seawater curve for the Cretaceous through the Eocene place limits on the resolution of strontium-isotope stratigraphy as applied to Leg 144 sediments. More detailed interpretations may only become possible as the ${ }^{87} \mathrm{Sr} /{ }^{86} \mathrm{Sr}$ curve is better defined at (or, in the case of the Paleocene-Eocene, possibly beyond) the limits of modern mass spectrometry.

This paper presents the results of ${ }^{87} \mathrm{Sr} /{ }^{86} \mathrm{Sr}$ measurements conducted on Leg 144 shallow-water carbonates plus vein and vesicle carbonate precipitated in basalt recovered from Holes $871 \mathrm{C}, 872 \mathrm{~B}$, 877A, 878A, and 879A drilled into Limalok, Lo-En, Wodejebato, MIT and Takuyo-Daisan guyots, respectively (see site map preceding title page). A detailed interpretation of the Sr-isotope data is only possible for shallow-water carbonates from Hole $877 \mathrm{~A}$, for which full constraints were placed on the state of sample preservation/diagenesis by integrating results with petrology plus stable isotopic and elemental geochemistry (Opdyke et al., this volume). Only a preliminary account is given of the processes defining the strontium-isotope depth profiles in the other holes because these samples have yet to be geochemically constrained for diagenesis.

Despite the complications discussed above, strontium-isotope geochemistry has helped constrain various elements of carbonate platform stratigraphy, carbonate platform diagenesis, and basaltseawater interaction. 
Figure $1 .{ }^{87} \mathrm{Sr} /{ }^{86} \mathrm{Sr}$ seawater curves. A. For the last $150 \mathrm{Ma}$. Data show a well-constrained, rapid, monotonic increase over the past $40 \mathrm{Ma}$ but little change between 65 and $40 \mathrm{Ma}$. B. For 150-50 Ma. Data show a well-constrained monotonic increase for Campanian/Maastrichtian time. Data for the Aptian and Albian are sparse. However, ${ }^{87} \mathrm{Sr} /{ }^{86} \mathrm{Sr}$ measurements on carefully selected skeletal calcite suggest that seawater ${ }^{87} \mathrm{Sr} /{ }^{86} \mathrm{Sr}$ fell from a mid-Barremian peak $(0.70750)$ to a minimum ( $\leq 0.70725$ ) around the Aptian/Albian boundary, and then rose through the Albian to $\sim 0.70745$ at the Albian/ Cenomanian boundary (Jones et al., 1994). Data sources are as follows: 0-9 Ma = solid circles from Hodell et al. (1989, 1990, 1991); 9-24 Ma = open circles from Oslick et al. (1994); 24-37 Ma = solid triangles from Miller et al. (1988); $37-69 \mathrm{Ma}=$ open triangles from Hess et al. $(1986,1989)$; 69-97 Ma = solid squares from McArthur et al. (1993b, 1994); and $>97 \mathrm{Ma}=$ open squares from Jones (1992).

Numeric ages from the time scales of Berggren et al. (1985b) for 0-69 Ma; from Obradovich (1993) for 69-95 Ma; and from Harland et al. (1990) for $>95 \mathrm{Ma}$. All data have been adjusted to a value of 0.709175 for modern seawater $\mathrm{Sr}$.
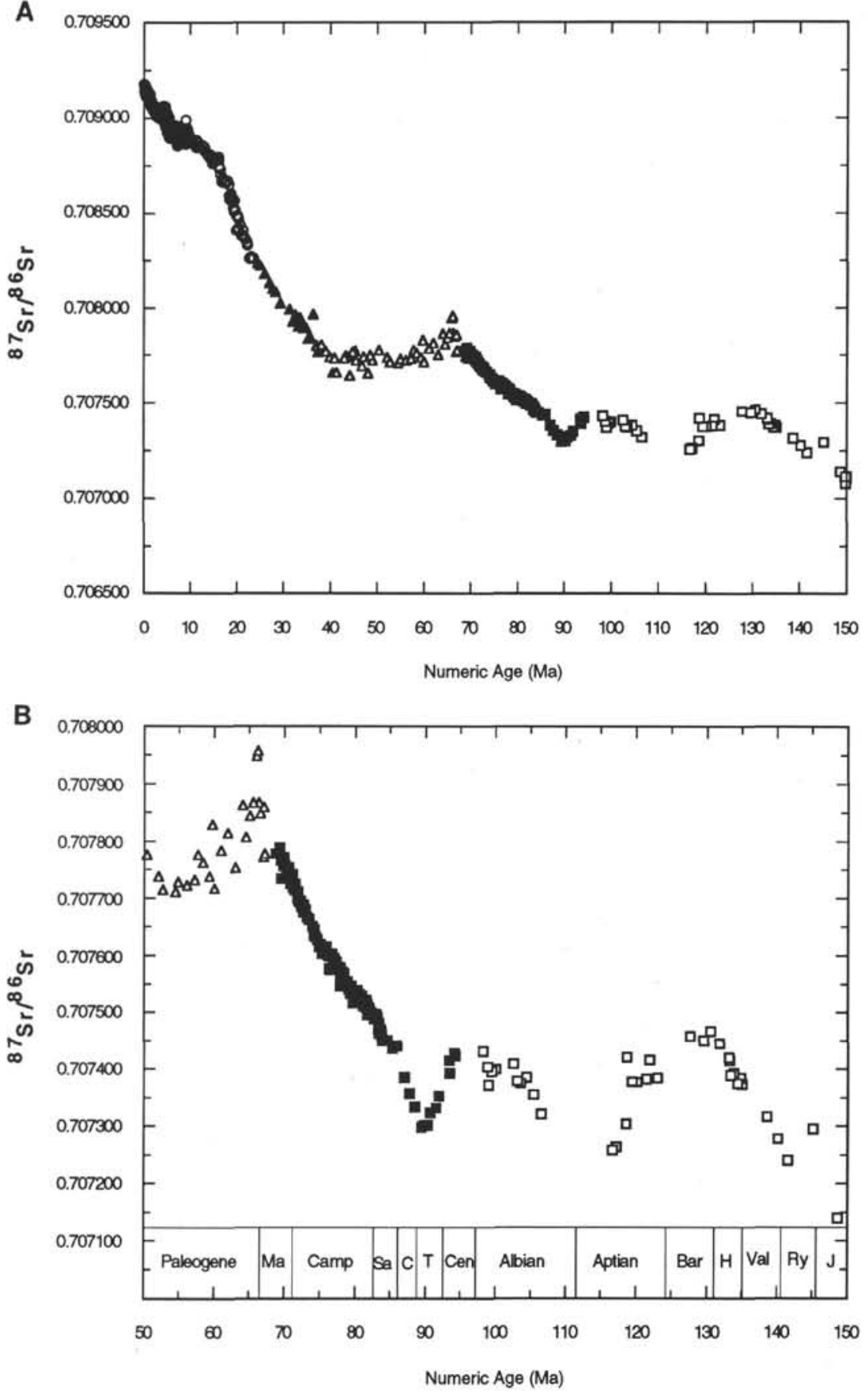

\section{METHODS}

Where core recovery and sampling protocol permitted, shallowwater platform carbonates plus vein and vesicle carbonate precipitated in basalt were collected at regular intervals. Rock chips were sliced in half at Cambridge using an ultra-thin ( $1 \mathrm{~mm}$ thick) diamond saw. One half of the chip was pressure-impregnated and thinsectioned along its cut face. The other half of the chip was polished along its cut face. More than 300 microsamples of powdered carbonate (approximately $2.0 \mathrm{mg}$ ) were drilled from the polished chips using a binocular microscope-mounted drill assembly. Sampling was based on the results of standard light microscopy and cathodoluminescence examination of the thin-sectioned chip and binocular microscopic examination of the polished chip. Sample collection was aimed at covering a wide range of depositional components in various states of

textural preservation plus diagenetic phases (e.g., cements) over as full a range of depths as possible. Microsamples were split into two $\sim 1.0 \mathrm{mg}$ subsamples: one set of these subsamples to be analyzed for elemental and stable isotopic compositions, the other set to be analyzed for strontium isotopes.

Leg 144 shallow-water carbonates best suited to the techniques described were well-cemented rudstones and boundstones such as those recovered from the perimeter of Wodejebato Guyot in Hole 877A. Poorly cemented, friable mudstones, wackestones, packstones, and grainstones recovered from the centers of Limalok (Hole 871C) and MIT (Hole 878A) guyots were difficult to separate, even with microsampling techniques. Consequently, analyses on these types of carbonates were, in practice, occasionally conducted on "bulk-rock microsamples," which were carefully selected for the homogeneous extent of cementation. 
Strontium was separated using a strontium-specific resin $(\mathrm{Sr}$ SPEC, Eichrom Industries) eluted with $3 \mathrm{M}$ nitric acid. ${ }^{87} \mathrm{Sr} /{ }^{86} \mathrm{Sr}$ ratios were determined using a VG Sector 54 instrument employing a three collector multidynamic peak-switching program. The major ${ }^{88} \mathrm{Sr}$ peak was automatically focused to give a beam size of $1.5 \times 10^{-11} \downarrow( \pm 10 \%)$. Measurements of strontium peaks and background were taken over a time interval of $5 \mathrm{~s}$ for each cycle, with a 2 -s delay between cycles. The mean of 150 ratio measurements was taken for each sample, and ${ }^{87} \mathrm{Sr} /{ }^{\beta 6} \mathrm{Sr}$ measurements were normalized exponentially to ${ }^{86} \mathrm{Sr} /{ }^{88} \mathrm{Sr}=$ 0.1194 . Usually, data were collected without internal rejection, although occasionally outliers were rejected at the 2.5 or $3.0 \sigma$ level. Examination of results for the SRM $987 \mathrm{SrCO}_{3}$ standard showed no significant differences between isotopic values recorded before and after rejection. During the course of this work, the SRM $987 \mathrm{SrCO}_{3}$ standard yielded ${ }^{87} \mathrm{Sr} /{ }^{86} \mathrm{Sr}=0.710254 \pm 24 \times 10^{-6}(2 \sigma), N=23$, and an in-house modern coral standard yielded ${ }^{87} \mathrm{Sr} /{ }^{86} \mathrm{Sr}=0.709177 \pm 24$. $10^{-6}(2 \sigma), N=25$.

\section{RESULTS}

Sr-isotopic determinations were performed on 120 carbonate samples from Holes $871 \mathrm{C}, 872 \mathrm{~B}, 877 \mathrm{~A}, 878 \mathrm{~A}$, and 879A drilled into Limalok, Lo-En, Wodejebato, MIT, and Takuyo-Daisan guyots, respectively (see site map preceding title page). Samples came from shallow-water limestones plus vein and vesicle carbonate precipitated in basalt. The complete set of ${ }^{87} \mathrm{Sr} /{ }^{86} \mathrm{Sr}$ measurements for the samples is given in Table 1 and illustrated as profiles in Figures 2-6.

\section{Hole 871C}

Hole $871 \mathrm{C}$ was drilled into the south central portion of Limalok Guyot, approximately $53.7 \mathrm{~km}$ from Mili Atoll in the southern Marshall Islands (see site map preceding title page). The shallow-water carbonates recovered from this hole are Paleocene bioclastic grainstones and packstones (Subunits IID-IIF, 316.7-422.9 mbsf) and overlying lower Eocene miliolid mudstones and wackestones (Subunits IIA-IIC, 153.2-316.7 mbsf) (Premoli Silva, Haggerty, Rack, et al., 1993, p. 51). The volcanic rocks recovered from Hole $871 \mathrm{C}$ are nepheline-bearing alkalic basalts pervasively altered (alteration features include veins of calcite 1-2 mm thick) by low-temperature hydrothermal fluids (Premoli Silva, Haggerty, Rack, et al., 1993, p. 72). The strontium-isotope stratigraphy of the lower Eocene shallowwater carbonates of Hole $871 \mathrm{C}$ is presented elsewhere (Wyatt et al., this volume). Here we present the strontium-isotope geochemistry of the Paleocene shallow-water carbonates plus vein carbonate precipitated in basalt from Hole 871C (Table 1 and Fig. 2).

In general, ${ }^{87} \mathrm{Sr} /{ }^{86} \mathrm{Sr}$ measurements conducted on shallow-water carbonates from $\sim 317$ to $\sim 413$ mbsf in Hole $871 \mathrm{C}$ display minor variations $(\sim 0.70770-0.70780)$ and are consistent with their Paleocene shipboard biostratigraphic age assignments. However, cements, skeletal grains, and matrix microsamples (Samples 144-871C-25R-1, $18-28 \mathrm{~cm}$ (1 and 2); -30R-1, 80-85 cm (1); and -31R-1, 0-5 cm (1)) have ${ }^{87} \mathrm{Sr} /{ }^{86} \mathrm{Sr}$ values that are significantly more radiogenic than other samples measured in this hole (Table 1). (Note: Numbers in parentheses after sample identifiers denote different microsamples drilled from the same sample.) These radiogenic data yield apparent ages that are significantly younger $(21.5, \sim 31.0$, and $\sim 26.0 \mathrm{Ma})$ than the assigned stratigraphic age of the carbonate platform. ${ }^{87} \mathrm{Sr} /{ }^{86} \mathrm{Sr}$ measurements (0.70361-0.70394) conducted on vein carbonates precipitated in basalt in this hole contrast sharply with data from the overlying shallow-water carbonates.

\section{Hole 872B}

Hole 872B was drilled into the central portion of Lo-En Guyot, approximately $148.2 \mathrm{~km}$ from Anewetak (formerly Enewetak), a living atoll that shares the same volcanic pedestal in the Marshall
Islands (see site map preceding title page). Drilling on Anewetak indicated that the volcanic pedestal is overlain by more than $1200 \mathrm{~m}$ of Cenozoic shallow-water carbonates (Ladd and Schlanger, 1960). However, the shallow-water carbonates that had been interpreted from seismic data to lie between the pelagic cap and basaltic rocks at Lo-En were never encountered. Instead, drilling in Hole 872B recovered only a thin veneer of phosphatized, manganese oxide-encrusted chalk containing upper Santonian to middle Eocene microfossils before entering basalt (Premoli Silva, Haggerty, Rack, et al., 1993, p. 122). These volcanic rocks are olivine-bearing alkalic hawaiite basalts with alteration features including veins and vesicles of calcite 1-7 mm thick (Premoli Silva, Haggerty, Rack, et al., 1993, p. 132). ${ }^{87} \mathrm{Sr} /{ }^{86} \mathrm{Sr}$ measurements conducted on vein carbonate precipitated in these basalts show remarkable variation (Table 1 and Fig. 3).

\section{Hole 877A}

Hole $877 \mathrm{~A}$ was drilled into an inner perimeter ridge on the northeastern rim of Wodejebato Guyot in the Ralik Chain of the northern Marshall Islands, about $44 \mathrm{~km}$ northwest of Pikinni, a living atoll that shares the same volcanic pedestal (see site map preceding title page). The shallow-water carbonates recovered from this hole are Campanian skeletal packstones and grainstones plus overlying Maastrichtian algal, rudist rudstones and boundstones (Subunits IIA-IIE, 0.03-182.9 mbsf) (Premoli Silva, Haggerty, Rack, et al., 1993, p. 289). The volcanic rocks recovered from Hole $877 \mathrm{~A}$ are basaltic breccia with calcite alteration products occurring as thin $(0.5-7.0 \mathrm{~mm}$ thick) anastomosing veins (Premoli Silva, Haggerty, Rack, et al. 1993, p. 308).

In general, ${ }^{87} \mathrm{Sr} /{ }^{86} \mathrm{Sr}$ measurements conducted on well-preserved skeletal grains and cements (Opdyke et al., this volume) from algal, rudist rudstone and boundstone shallow-water carbonates between $\sim 0$ and 85 mbsf (especially at $\sim 41 \mathrm{mbsf}$ ) in Hole $877 \mathrm{~A}$ show minor variation (0.70775-0.70780) and are consistent with their Upper Cretaceous shipboard biostratigraphic age assignments (Table 1 and Fig. 4). However, a number of measurements conducted on other microsampled cements and cemented skeletal grainstones $(\sim 0-50$ and $\sim 120-180 \mathrm{mbsf}$ ) are significantly more radiogenic (Table 1 and Fig. 4). These radiogenic data yield apparent ages that are much younger $(\sim 32-18 \mathrm{Ma})$ than the assigned stratigraphic age of the carbonate platform. A single ${ }^{87} \mathrm{Sr} /{ }^{86} \mathrm{Sr}$ measurement $(0.70714)$ conducted on vein carbonate Sample 144-877A-20R-5, 28-30 cm (1), precipitated in basalt in this hole is significantly less radiogenic than the data from the overlying shallow-water carbonates.

\section{Hole 878A}

Hole $878 \mathrm{~A}$ was drilled behind the southern edge of the northeastern part of MIT Guyot, an isolated feature close to the Wake Group in the $18^{\circ}-28^{\circ} \mathrm{N}$ guyot band. The lower, 120 -m-thick, shallowwater carbonates recovered from this hole ( $600-730 \mathrm{mbsf})$ are lower Aptian skeletal-oolitic grainstones and peloid foraminiferal packstones/wackestones (Units VII-V; Premoli Silva, Haggerty, Rack, et al., 1993, p. 346). These units are overlain by $\sim 200 \mathrm{~m}$ of limestonevolcaniclastic breccia representing a short-lived volcanic eruption through the carbonate platform. This breccia is overlain by $\sim 400 \mathrm{~m}$ of upper Aptian to Albian peloid grainstone and gastropod wackestone shallow-water carbonates (Units IV-II; Premoli Silva, Haggerty, Rack, et al., 1993, p. 346). Hole 878A is the only Leg 144 site with significant basalt recovery at which calcite veins are not prevalent; within it are recorded three distinct periods of subaerial volcanism with intervening weathering intervals and a fourth near-shore, shallow-marine episode (Premoli Silva, Haggerty, Rack, et al., 1993, p. 374).

All ${ }^{87} \mathrm{Sr} /{ }^{86} \mathrm{Sr}$ measurements $(\sim 0.70726-0.70751)$ conducted on shallow-water carbonates from Hole $878 \mathrm{~A}$ are consistent with their mid-Cretaceous shipboard biostratigraphic age assignments (Table 1 and Fig. 5). ${ }^{87} \mathrm{Sr} /{ }^{86} \mathrm{Sr}$ measurements $(0.70351-0.70709)$ conducted on 
Table 1. Downhole ${ }^{87} \mathrm{Sr} /{ }^{86} \mathrm{Sr}$ measurements conducted on microsampled solid carbonates listed from Holes 871C, 872B, 877A, 878A, and 879A.

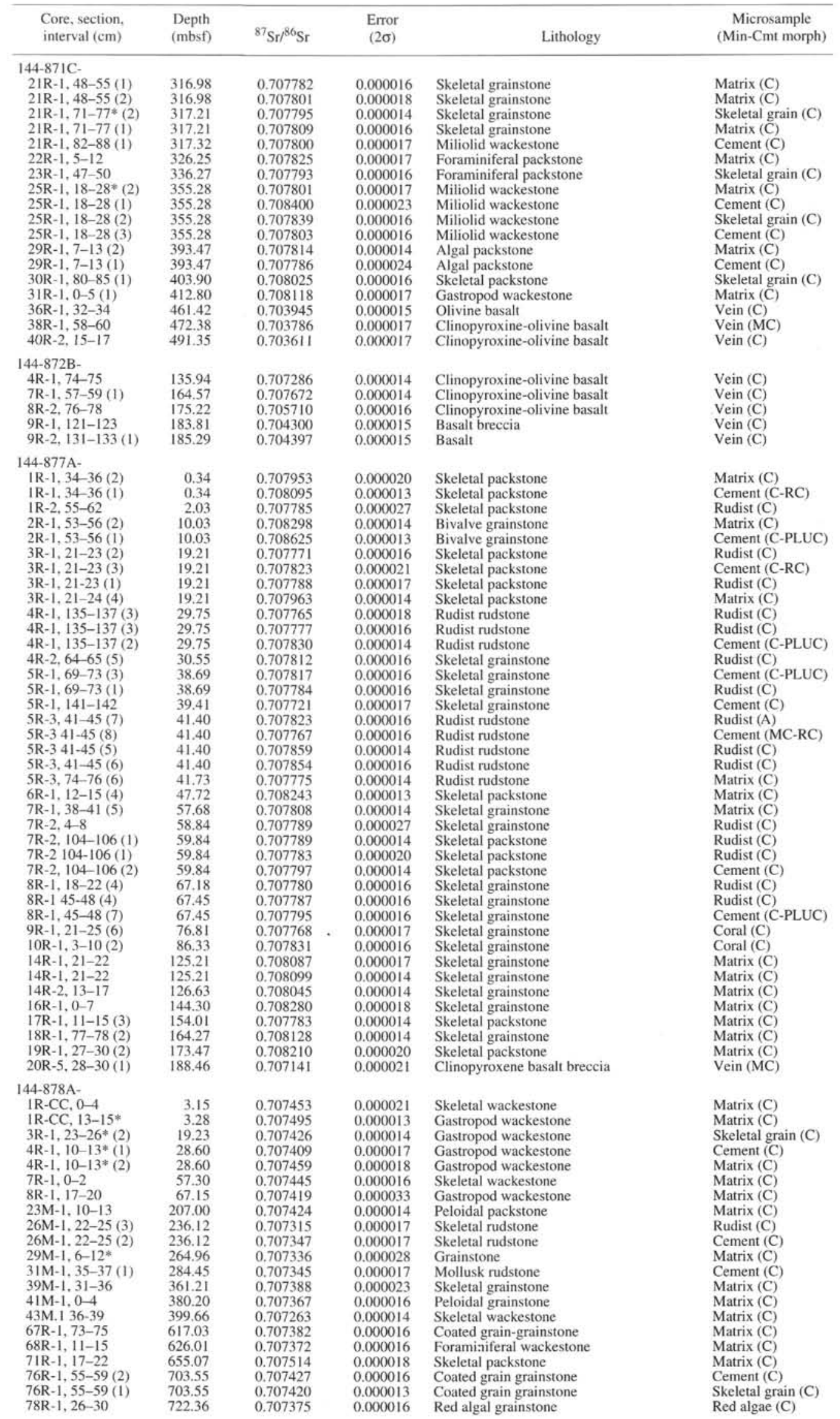


Table 1 (continued).

\begin{tabular}{|c|c|c|c|c|c|}
\hline $\begin{array}{l}\text { Core, section, } \\
\text { interval }(\mathrm{cm})\end{array}$ & $\begin{array}{l}\text { Depth } \\
\text { (mbsf) }\end{array}$ & ${ }^{87} \mathrm{Sr} /{ }^{86} \mathrm{Sr}$ & $\begin{array}{l}\text { Error } \\
(2 \sigma)\end{array}$ & Lithology & $\begin{array}{c}\text { Microsample } \\
\text { (Min-Cmt morph) }\end{array}$ \\
\hline $80 \mathrm{R}-2,127-129$ & 744.17 & 0.707093 & 0.000017 & Olivine basalt & Vein $(C)$ \\
\hline $81 \mathrm{R}-3,80-83$ & 754.45 & 0.705430 & 0.000042 & Olivine basalt & Vein (C) \\
\hline $84 R-6,30-35$ & 787.53 & 0.703519 & 0.000014 & Olivine-clinopyroxene-plagioclase basalt & Vesicle (C) \\
\hline $85 \mathrm{R}-1,44-49$ & 789.74 & 0.704846 & 0.000013 & Olivine basalt & Vesicle (C) \\
\hline $88 R-3,47-50$ & 821.18 & 0.703843 & 0.000015 & Olivine-clinopyroxene basalt & Vein $(C)$ \\
\hline $93 R-2,89-93$ & 868.08 & 0.703778 & 0.000031 & Olivine-clinopyroxene-plagioclase basalt & Vein (C) \\
\hline $98 \mathrm{R}-3,0-3$ & 906.79 & 0.703754 & 0.000046 & Olivine-clinopyroxene-plagioclase basalt & Vein (C) \\
\hline \multicolumn{6}{|l|}{$144-879 \mathrm{~A}-$} \\
\hline IR-I, 15-20* (3) & 0.15 & 0.707406 & 0.000023 & Mollusk rudstone & Cement (C) \\
\hline $1 \mathrm{R}-1,15-20 *(4)$ & 0.15 & 0.707399 & 0.000018 & Mollusk rudstone & Matrix (C) \\
\hline $2 \mathrm{R}-1,4-11(1)$ & 6.04 & 0.707435 & 0.000016 & Bivalve rudstone & Cement (C) \\
\hline \multicolumn{6}{|l|}{$144-897 \mathrm{~A}$ - } \\
\hline $2 \mathrm{R}-1,4-11(2)$ & 6.04 & 0.707321 & 0.000014 & Bivalve rudstone & Rudist (C) \\
\hline $2 R-2,11-15(1)$ & 7.61 & 0.707292 & 0.000016 & Mollusk packstone & Rudist (C) \\
\hline $4 \mathrm{R}-1,0-9(1)$ & 25.00 & 0.707309 & 0.000016 & Oyster floatstone & Oyster (C) \\
\hline $4 \mathrm{R}-1,0-9(2)$ & 25.00 & 0.707267 & 0.000014 & Oyster floatstone & Cement (C) \\
\hline $5 R-1,26-31(2)$ & 34.86 & 0.707390 & 0.000016 & Foraminiferal grainstone & Matrix (C) \\
\hline $5 \mathrm{R}-1,26-31$ (3) & 34.86 & 0.707380 & 0.000017 & Foraminiferal grainstone & Cement (C) \\
\hline $6 \mathrm{R}-1,9-12(1)$ & 44.39 & 0.707210 & 0.000014 & Mollusk wackestone & Cement (C) \\
\hline $6 \mathrm{R}-1,9-12(2)$ & 44.39 & 0.707296 & 0.000014 & Mollusk wackestone & Oyster (C) \\
\hline $11 \mathrm{R}-1,11-17$ (1) & 92.61 & 0.707223 & 0.000016 & Skeletal rudstone & Rudist (C) \\
\hline $14 \mathrm{R}-1,13-18^{*}$ & 121.63 & 0.707290 & 0.000024 & Peloidal packstone & Matrix (C) \\
\hline $14 \mathrm{R}-1,37-41$ & 121.87 & 0.707251 & 0.000016 & Peloidal packstone & Matrix (C) \\
\hline $15 R-1,38-41$ & 131.48 & 0.707343 & 0.000014 & Packstone & Matrix (C) \\
\hline $16 \mathrm{R}-1,104-108(2)$ & 141.84 & 0.707362 & 0.000014 & Skeletal wackestone & Matrix (C) \\
\hline $17 \mathrm{R}-2,84-88(1)$ & 152.76 & 0.707212 & 0.000014 & Calcareous sandstone & Cement (C) \\
\hline $17 \mathrm{R}-2,86-88(2)$ & 152.76 & 0.707272 & 0.000014 & Calcareous sandstone & Matrix (C) \\
\hline $18 \mathrm{R}-1,0-3$ & 160.10 & 0.707268 & 0.000016 & Gastropod rudstone & Rudist (C) \\
\hline $21 \mathrm{R}-2,55-58$ & 190.75 & 0.706705 & 0.000016 & Plagioclase basalt & Vein (C) \\
\hline $2 \mathrm{R}-1,51-53$ & 198.61 & 0.706594 & 0.000016 & Plagioclase basalt & $\operatorname{Vein}(\mathrm{C})$ \\
\hline $22 \mathrm{R}-2,129-134$ & 200.76 & 0.706763 & 0.000016 & Plagioclase basalt & Vein $(C)$ \\
\hline $22 \mathrm{R}-4,117-118$ & 203.56 & 0.706638 & 0.000014 & Plagioclase basalt & Vein $(\mathrm{C})$ \\
\hline $22 \mathrm{R}-6,0-3$ & 205.23 & 0.706750 & 0.000016 & Plagioclase basalt & Vein $(C)$ \\
\hline $22 \mathrm{R}-7,97-99$ & 207.52 & 0.706840 & 0.000014 & Plagioclase basalt & Vein $(C)$ \\
\hline $23 R-4,145-148$ & 213.50 & 0.706888 & 0.000014 & Volcanic breccia & Vein $(C)$ \\
\hline
\end{tabular}

Notes: Numbers in parentheses after sample numbers identify different microsamples drilled from the same sample. A single asterisk $\left({ }^{*}\right)$ denotes that the sample was too small to prepare a thin section along the cut face. Microsample descriptions: Matrix = carefully selected "bulk rock" microsample; Min $=$ mineralogy; $\mathrm{Cmt}$ morph $=$ cement morphology; $\mathrm{C}=$ calcite; $\mathrm{MC}=$ magnesian calcite; $\mathrm{A}=$ aragonite; $\mathrm{RC}=$ radiaxial cement; $\mathrm{PLUC}=$ pyramidal, limpid, uniform extinction cement. Hole $877 \mathrm{~A}$ cement descriptions after table 1 in Opdyke et al. (this volume).

vein and vesicle carbonates precipitated in basalt in this hole show remarkable variation, but all are significantly less radiogenic than data from the overlying shallow-water carbonates.

\section{Hole 879A}

Hole 879A was drilled into the southern perimeter ridge of TakuyoDaisan Guyot, the easternmost guyot of the Seiko cluster of seamounts in the $30^{\circ}-35^{\circ} \mathrm{N}$ guyot band (see site map preceding title page). The shallow-water carbonates recovered from this hole are upper Aptian calcareous sandstones and conglomerates, argillaceous limestones with volcanic grains, and pyrite, plus skeletal wackestones overlain by upper Aptian-Albian skeletal packstones/wackestones and coral-mollusk rudstones/packstones (Units II-I; Premoli Silva, Haggerty, Rack, et al., 1993, p. 421). The volcanic rocks recovered from Hole $879 \mathrm{~A}$ are plagioclase-phyric/peperite basalts with reddish discoloration to the microcrystalline matrix and distinct iron-stained alteration fronts in the vicinity of veins reflecting pervasive alteration (Premoli Silva, Haggerty, Rack, et al., 1993, p. 430).

${ }^{87} \mathrm{Sr} /{ }^{86} \mathrm{Sr}$ measurements $(\sim 0.70721-0.70743)$ conducted on shallow-water carbonates from Hole 879A are all consistent with their mid-Cretaceous shipboard biostratigraphic age assignments (Table 1 and Fig. 6). ${ }^{87} \mathrm{Sr} /{ }^{86} \mathrm{Sr}$ measurements $(0.70659-0.70688)$ conducted on vein carbonate precipitated in basalt in this hole are remarkably consistent with each other and show a general increase with depth.

\section{DISCUSSION}

The results presented above help fulfill Leg 144 objectives as previously listed because they contribute information on carbonate platform stratigraphy, carbonate platform diagenesis, and basaltseawater interaction.

\section{Carbonate Platform Stratigraphy}

Existing models for global sea-level change are built almost exclusively on analyses of passive margin sequences and calculations of ice volume traced through the deep-sea $\delta^{18} \mathrm{O}$ foraminiferal record. Such models may be tested against the sea-level histories recorded in carbonate platforms. Application of strontium-isotope stratigraphy to studies of upper Cenozoic platform carbonates has resulted in several eustatic sea-level reconstructions from Pacific atolls (e.g., Ludwig et al., 1988; Quinn and Matthews, 1990; Lincoln and Schlanger, 1991; Quinn et al., 1991; Wheeler and Aharon, 1991; Ohde and Elderfield, 1992; Aharon et al., 1993). The success of strontium-isotope stratigraphy depends on the existence of a well-defined, rapid, and monotonically changing ${ }^{87} \mathrm{Sr} /{ }^{86} \mathrm{Sr}$ seawater curve. Unfortunately, this condition is not readily met for the Paleogene (e.g., Koepnick et al., 1985, 1988; Hess et al., 1986; Denison et al., 1993; P.A. Wilson et al., unpubl. data). Therefore, at the limits of modern mass spectrometry, severe limits are placed on the resolution of strontium-isotope stratigraphy as applied to shallow-water carbonates from Limalok Guyot. However, recent improvements to the ${ }^{87} \mathrm{Sr} /{ }^{86} \mathrm{Sr}$ seawater curve for the Cretaceous allow us to place certain constraints on the stratigraphy of shallow-water carbonates recovered from Wodejebato, MIT, and Tayuko-Daisan guyots (Koepnick et al., 1985, 1988; Jones, 1992; Jones et al., 1994; McArthur et al., 1992, 1993a, 1993b, 1994).

The exact position of the Campanian/Maastrichtian boundary cannot be identified on the basis of biostratigraphy in any of the holes (Sites 873-877) drilled into Wodejebato Guyot (Premoli Silva et al., this volume). Recent refinements to the ${ }^{87} \mathrm{Sr} /{ }^{86} \mathrm{Sr}$ seawater curve for the Campanian/Maastrichtian (McArthur et al., 1993b, 1994) makes these stages perhaps the best suited of all Cretaceous stages to strontiumisotope stratigraphy. Based on this refined reference curve (Fig. 1B), ${ }^{87} \mathrm{Sr} /{ }^{86} \mathrm{Sr}$ measurements in the range of $0.70775-0.70780$ conducted on 


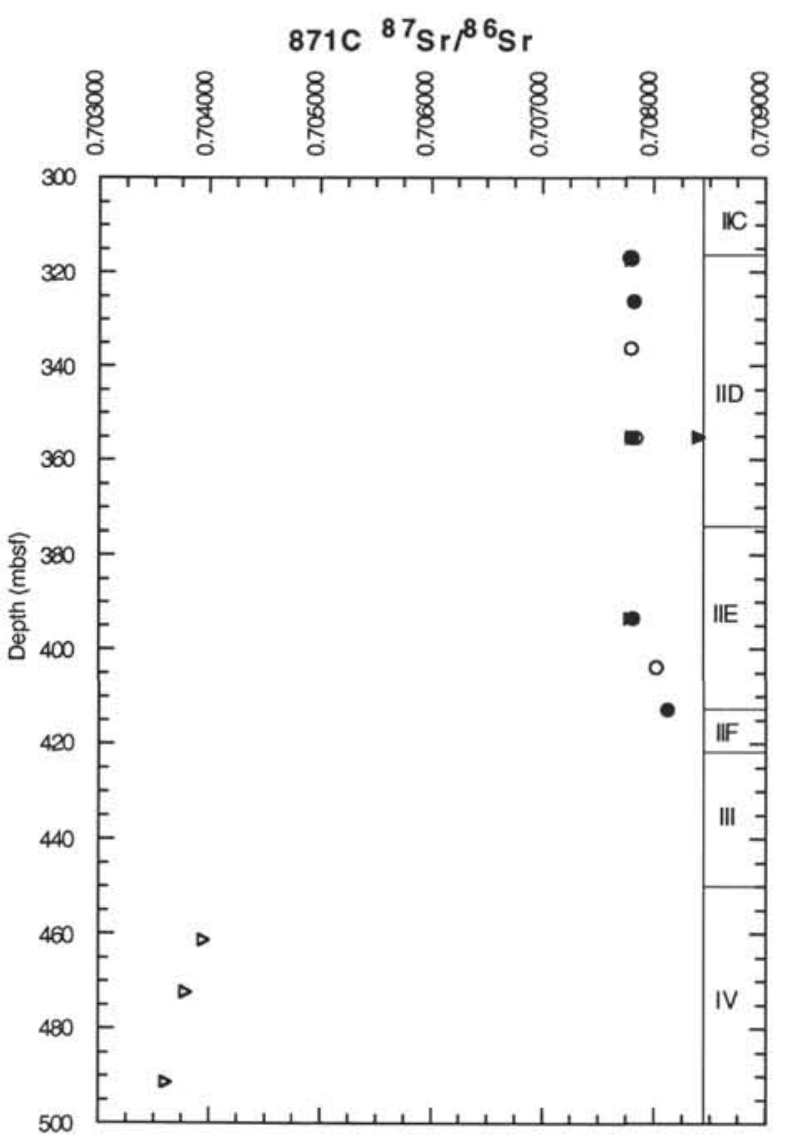

Figure 2. Depth profile for ${ }^{87} \mathrm{Sr} /{ }^{86} \mathrm{Sr}$ measurements conducted on shallowwater platform carbonates and carbonates precipitated in basalt in Hole 871C. Solid circles $=$ matrix, hollow circles $=$ skeletal grain, solid triangles $=$ cement, and hollow triangles $=$ vein/vesicle carbonate. Lithologic units and subunits: IIC $=$ benthic foraminifer packstone and wackestones; IID = coralline grain stone, rudstone, and packstone; $\mathrm{IIE}=$ rhodolith grainstone and packstone; IIF $=$ dark gray skeletal packstone; $\mathrm{III}=$ mottled/variegated clay; and $\mathrm{IV}=$ basalt.

the well-preserved skeletal grains and cements between $\sim 0$ and 85 mbsf in Hole $877 \mathrm{~A}$ give an inferred oldest age of $\sim 70.5 \mathrm{Ma}$. These data are significantly more radiogenic than the Campanian/Maastrichtian boundary as defined by $\mathrm{Sr}$ isotopes $(0.70772 \approx 71.3 \mathrm{Ma}$; McArthur et al., 1993b, 1994). Consequently, strontium-isotope stratigraphy dates the upper $\sim 85 \mathrm{~m}$ of Hole $877 \mathrm{~A}$ as lower Maastrichtian.

Unfortunately, skeletal packstone and grainstone shallow-water carbonates below $\sim 85 \mathrm{mbsf}$ in Hole $877 \mathrm{~A}$ are unsuited to microsampling techniques and have undergone significant diagenesis, making them virtually impossible to date by strontium-isotope stratigraphy. A single measurement conducted on matrix Sample 144-877A-17R-1, $11-15 \mathrm{~cm}$ (3), is within error of those measurements conducted on the well-preserved skeletal grains and cements from above $\sim 85 \mathrm{mbsf}$. If this measurement is confirmed, then the ${ }^{87} \mathrm{Sr} /{ }^{86} \mathrm{Sr}$ profile for depositional carbonate through the upper $154 \mathrm{~m}$ of Hole $877 \mathrm{~A}$ is best represented as a vertical line through $\sim 0.70775-0.70780$. Such a profile would place the following constraints on the stratigraphy of the upper $154 \mathrm{~m}$ this hole: (1) carbonate platform sedimentation was not interrupted by hiatal surfaces associated with periods of platform exposure longer than $\sim 1 \mathrm{Ma}$ (resolution of strontium-isotope stratigraphy in the Late Cretaceous) and (2) the position of the Campanian/Maastrichtian boundary in Hole $877 \mathrm{~A}$ lies between $\sim 154$ and 182.9 mbsf, which is dated as upper Campanian on the basis of calcareous nannofossil biostratigraphy (Erba et al., this volume).

The ${ }^{87} \mathrm{Sr} /{ }^{86} \mathrm{Sr}$ Campanian/Maastrichtian boundary is defined on the basis of European sections that are well-dated by macrofossil

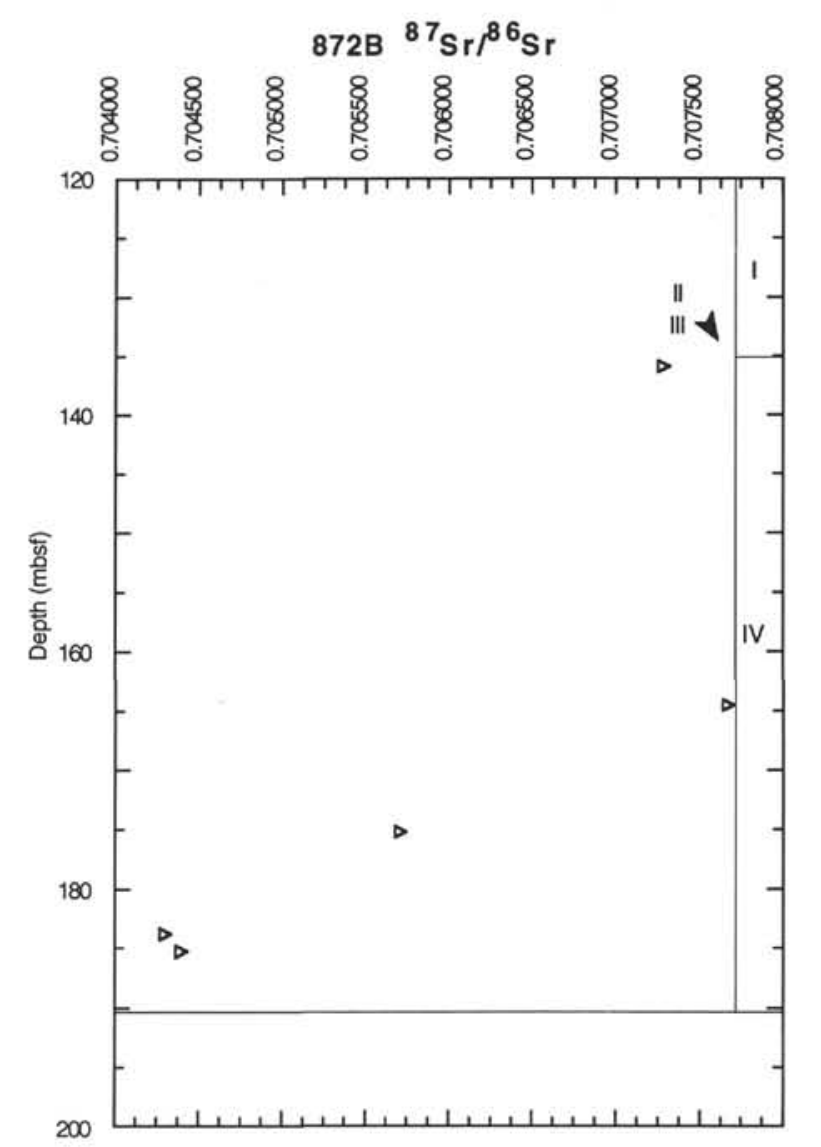

Figure 3. Depth profile for ${ }^{87} \mathrm{Sr} /{ }^{86} \mathrm{Sr}$ measurements conducted on carbonates precipitated in basalt in Hole $872 \mathrm{~B}$. Hollow triangles $=$ vein/vesicle carbonate. Lithologic units and subunits: $\mathrm{I}=$ nannofossil foraminifer ooze; $\mathrm{II}$ = chalkbasalt pebble conglomerate; $\mathrm{III}=$ limestone-basalt pebble conglomerate; and IV = basalt with planktonic foraminiferal limestone filling fractures.

biostratigraphy (McArthur et al., 1993b, 1994). However, there is considerable "elasticity" in the placement of this boundary between macrofossil, microfossil, and nannofossil stratigraphy (Burnett et al., 1992). Consequently, supporting ${ }^{87} \mathrm{Sr} /{ }^{86} \mathrm{Sr}$ data from other holes in Wodejebato may well be necessary to refine the placement of the Campanian/Maastrichtian boundary in this guyot.

The results of strontium-isotope stratigraphy from the shallowwater carbonates in Holes $878 \mathrm{~A}$ and $879 \mathrm{~A}$ are preliminary because of inadequacies in both the guyot data and the ${ }^{87} \mathrm{Sr} /{ }^{86} \mathrm{Sr}$ seawater reference curve for the mid-Cretaceous. Coverage of the strontium-isotope data from the shallow-water carbonates in Holes $878 \mathrm{~A}$ and $879 \mathrm{~A}$ is patchy and samples have not yet been constrained geochemically for their state of preservation/diagenesis. Similarly, the ${ }^{87} \mathrm{Sr} /{ }^{86} \mathrm{Sr}$ seawater curve for the Aptian/Albian remains sparse and scattered (Fig. 1). Scatter is caused by diagenetic alteration of bulk-rock carbonates (Koepnick et al., 1990). However, ${ }^{87} \mathrm{Sr} /{ }^{86} \mathrm{Sr}$ measurements on carefully selected skeletal calcite suggest that seawater ${ }^{87} \mathrm{Sr} /{ }^{86} \mathrm{Sr}$ fell from a mid-Barremian peak $(0.70750)$ to a minimum $(\leq 0.70725)$ around the Aptian/Albian boundary, and then rose through the Albian to $\sim 0.70745$ at the Albian/Cenomanian boundary (Jones, 1992; Jones et al., 1994).

Although geochemical constraints on diagenesis have yet to be placed on shallow-water carbonate samples from Holes $878 \mathrm{~A}$ and $879 \mathrm{~A}$, coverage of ${ }^{87} \mathrm{Sr} /{ }^{86} \mathrm{Sr}$ measurements in these holes is relatively patchy, and the Aptian/Albian reference curve is embryonic, the potential for correlating these three records as more data become available appears promising (Figs. 1B, 5, and 6). All ${ }^{87} \mathrm{Sr} /{ }^{86} \mathrm{Sr}$ measurements $(\sim 0.70726-0.70751$ and $\sim 0.70721-0.70743)$ conducted on microsampled shallow-water carbonates from Holes $878 \mathrm{~A}$ and $879 \mathrm{~A}$, 


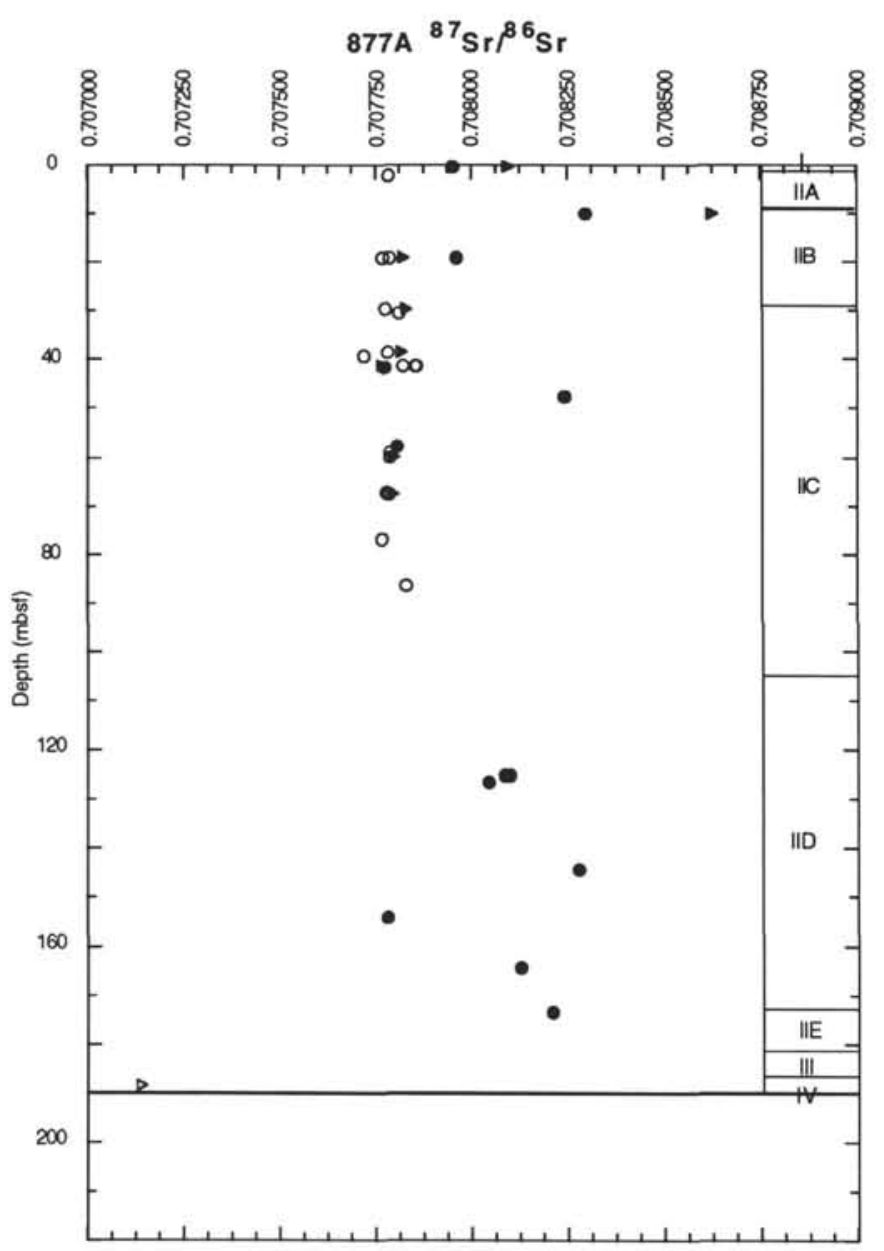

Figure 4. Depth profile for ${ }^{87} \mathrm{Sr} /{ }^{86} \mathrm{Sr}$ measurements conducted on shallowwater platform carbonates and carbonates precipitated in basalt in Hole $877 \mathrm{~A}$. Solid circles $=$ matrix , hollow circles $=$ skeletal grain, solid triangles $=$ cement , and hollow triangles $=$ vein/vesicle carbonate. Lithologic units: $\mathrm{I}=$ manganese crust; $\mathrm{IIA}=$ algal rudist boundstone $; \mathrm{IB}=$ skeletal fenestral wackestone and rudist algal packstone/grainstone; IIC $=$ algal rudist rudstone, floatstone, grainstone, and boundstone; IID = foraminifer skeletal grainstone; IIE = skeletal foraminifer packstone, grainstone, and floatstone; $\mathrm{III}$ = clay, claystone, and claystone breccia; and IV = volcanic breccia.

respectively, are consistent with their mid-Cretaceous shipboard biostratigraphic age assignments (Table 1 and Fig. 5). If confirmed as a primary signature, one measurement conducted on skeletal rudist Sample 144-878A-26M-1, 22-25 cm (3) (Table 1 and Fig. 5), would suggest that the position of the Aptian/Albian boundary may be around 235 mbsf in Hole $878 \mathrm{~A}$, as suggested by the calcareous nannofossil biostratigraphy (Erba et al., this volume). Perhaps the most important observation with reference to strontium-isotope stratigraphy in MIT and Tayuko-Daisan guyots is that, despite diagenetic scatter, ${ }^{87} \mathrm{Sr} /{ }^{86} \mathrm{Sr}$ data from the top of Hole $879 \mathrm{~A}$ are generally less radiogenic $(\approx 0.00005)$ than their Hole $878 \mathrm{~A}$ counterparts. If these data are confirmed and the ${ }^{87} \mathrm{Sr} /{ }^{86} \mathrm{Sr}$ seawater reference curve does rise from a minimum $(\leq 0.70725)$ around the Aptian/Albian boundary, through the Albian to 0.70745 at the Albian/Cenomanian boundary, then strontium-isotope stratigraphy might suggest that TayukoDaisan Guyot drowned earlier (early Late Albian) than MIT Guyot (latest Albian). The importance of placing better constraints on the timing of platform drowning should be emphasized because it is essential to determining the factors that cause atolls to drown (i.e., guyot origin; Erba et al., 1993; Winterer et al., 1993; Larson et al., this

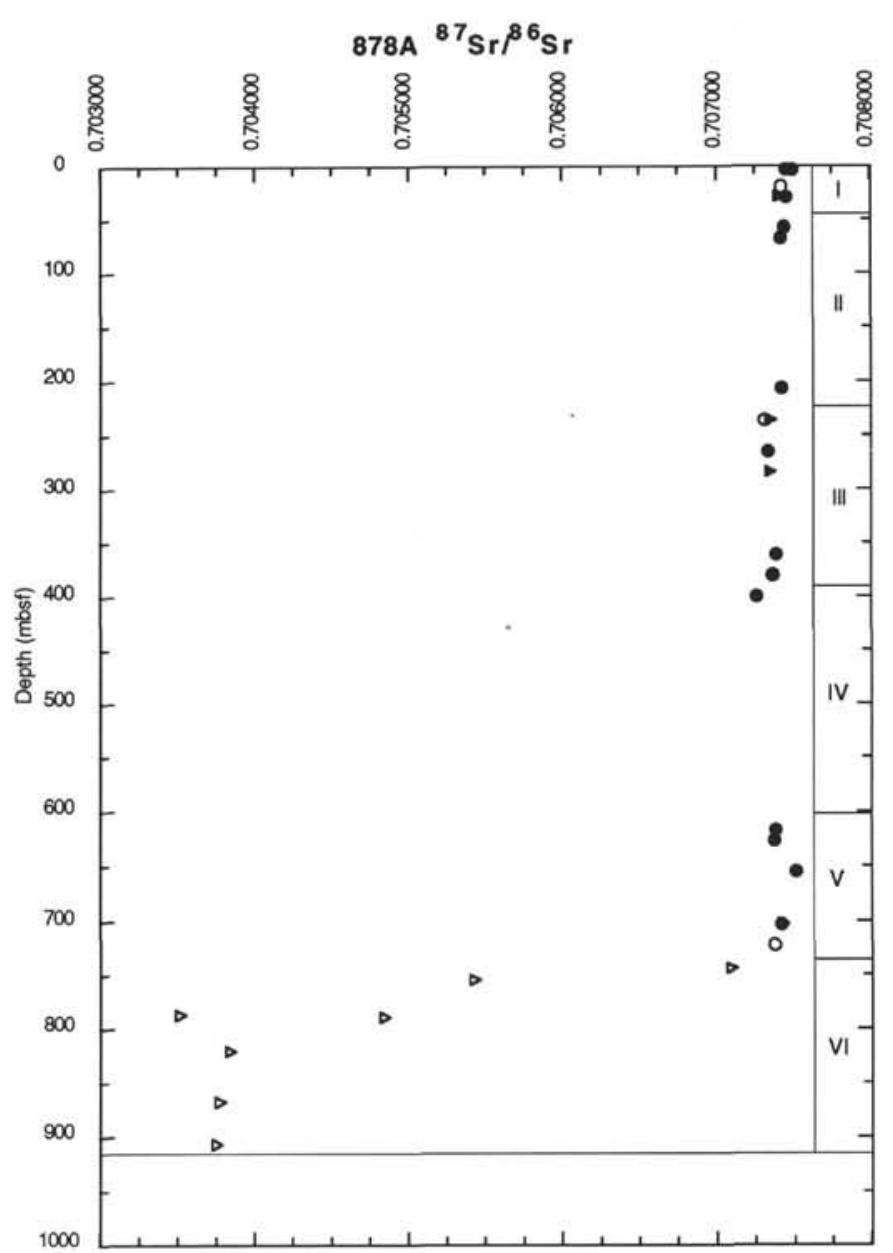

Figure 5. Depth profile for ${ }^{87} \mathrm{Sr} /{ }^{86} \mathrm{Sr}$ measurements conducted on shallowwater platform carbonates and carbonates precipitated in basalt in Hole 878A. Solid circles $=$ matrix, hollow circles $=$ skeletal grain, solid triangles $=$ cement, and hollow triangles $=$ vein/vesicle carbonate. Lithologic units: $\mathrm{I}=$ foraminifer nannofossils and manganese crust and nodules; $\mathrm{II}=$ skeletal wackestone and packstones; III = fine to medium, friable, skeletal grainstone; IV = volcanic breccia; $\mathrm{V}=$ peloidal foraminifer wackestone and packstone, and oolitic skeletal grainstone; and VI = alkalic basalt flows with flow-top breccias.

volume). In any case, it would appear that as more data become available (both for the guyot and for the ${ }^{87} \mathrm{Sr} /{ }^{86} \mathrm{Sr}$ seawater reference curve), strontium-isotope stratigraphy may help correlate MIT and Tayuko-Daisan not only with each other, but also to Resolution and Allison guyots, drilled during Leg 143 (Jenkyns et al., 1995).

\section{Carbonate Platform Diagenesis}

Chemical information on pore fluids from deep within cemented shallow-water carbonate platforms is extremely limited (Swart and Guzikowski, 1988; Elderfield et al., 1993; Paull et al., 1995; P.K. Swart et al., unpubl. data). Consequently, relatively few constraints have been placed on the wide range of hydrodynamic processes hypothesized as responsible for diagenesis in carbonate platforms (e.g., Saller, 1984; Simms, 1984; Whitaker and Smart, 1990).

Pore/borehole fluids were not collected from shallow-water carbonates cored during Leg 144 . In the absence of these data, geochemical analyses of microsampled diagenetic solid phases from these rocks provide the best means of constraining the timing and mode of fluid flow and diagenesis within shallow-water carbonate platforms of Pacific guyots. 


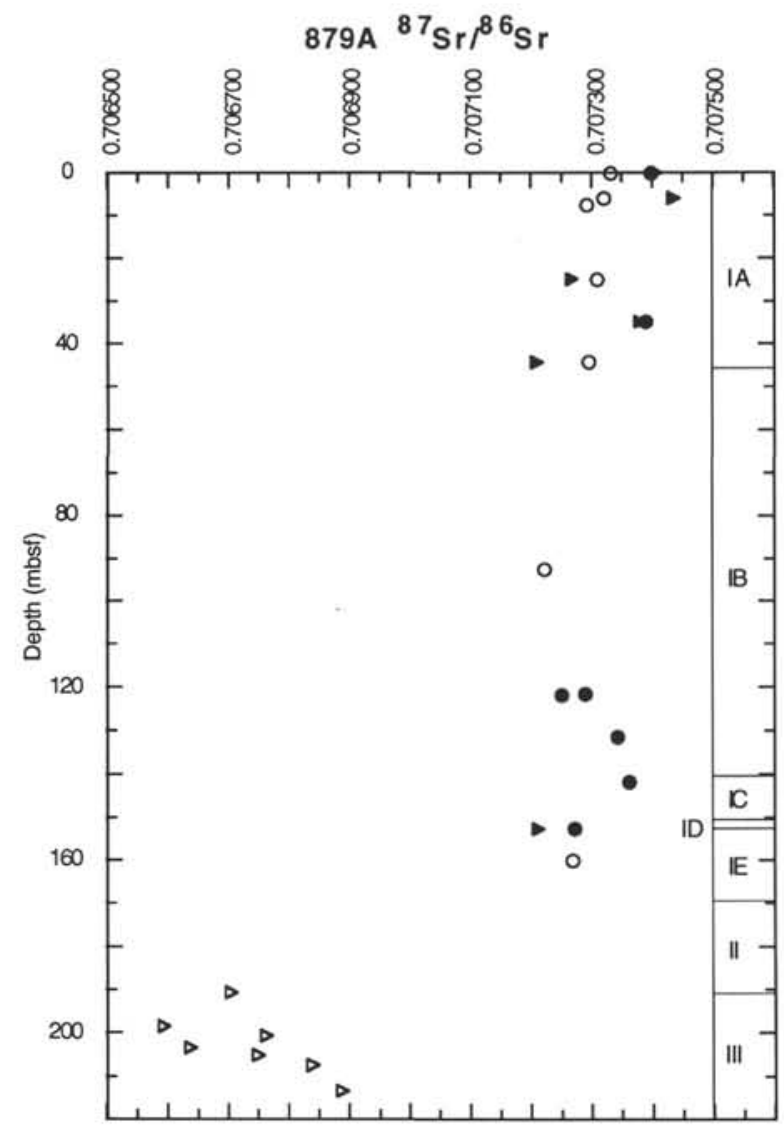

Figure 6. Depth profile for ${ }^{87} \mathrm{Sr} /{ }^{86} \mathrm{Sr}$ measurements conducted on shallowwater platform carbonates and carbonates precipitated in basalt in Hole 879A. Solid circles $=$ matrix, hollow circles $=$ skeletal grain, solid triangles $=$ cement, and hollow triangles $=$ vein/vesicle carbonate. Lithologic units and subunits: $\mathrm{IA}=$ coral-mollusk rudstone and floatstone; $\mathrm{IB}=$ skeletal packstone and wackestone; $\mathrm{IC}=$ skeletal wackestone with volcanic grains; ID = argillaceous limestone with organic intercalations; $\mathrm{IE}=$ calcareous sandstone and conglomerate rudstone; $\mathrm{II}=$ claystone with relict breccia texture; and $\mathrm{III}$ = basalt.

A detailed interpretation of Hole $877 \mathrm{~A}^{87} \mathrm{Sr} /{ }^{86} \mathrm{Sr}$ data is possible because these measurements may be integrated with petrological, stable isotopic, and elemental geochemical data (Opdyke et al., this volume). Algal, rudist rudstone, and boundstone shallow-water carbonates from $\sim 41 \mathrm{mbsf}$ in this hole show remarkable preservation of metastable carbonate minerals (Opdyke et al., this volume, plate 1). Early marine magnesian calcite cements ( $7 \mathrm{~mol} \% \mathrm{MgCO}_{3}, \delta^{18} \mathrm{O}=$ $-2.63 \%$ PDB, and $\delta^{13} \mathrm{O}=+2.97 \%$ PDB) envelop fragments of rudist bivalves that retain their original aragonite mineralogy and inferred original stable isotopic $\left(\delta^{18} \mathrm{O}=-2.83 \%\right.$ and $\left.\delta^{13} \mathrm{O}=+3.18 \%\right)$ and elemental $(\mathrm{Sr}=\sim 3,000 \mathrm{ppm}$ ) geochemistry (Opdyke et al., this volume, figs. 3-7). Calculated water temperatures from these rudist fragments and cements are similar to modern tropical sea-surface water temperatures $\left(\sim 27^{\circ} \mathrm{C}\right)$. Elsewhere in Hole $877 \mathrm{~A}$, metastable carbonate minerals have undergone diagenetic stabilization to low magnesian calcite, involving the loss of $\mathrm{Sr}$ and $\mathrm{F}$ (primary aragonite) and the loss of $\mathrm{Mg}$ (primary magnesian calcite) plus increases in $\delta^{18} \mathrm{O}$ (Opdyke et al., this volume, figs. 3-7). These geochemical patterns are associated with both neomorphic and dissolution/cementation processes. Little or no evidence of pervasive meteoric diagenesis is present in Hole $877 \mathrm{~A}$; instead, these diagenetic processes are interpreted to have taken place in colder, presumably less $\mathrm{CaCO}_{3}$-saturated, deeper marine waters (Opdyke et al., this volume).

Generally, ${ }^{87} \mathrm{Sr} /{ }^{86} \mathrm{Sr}$ measurements $(0.70775-0.70780)$ conducted on well-preserved magnesian calcite marine cements and aragonitic rudists plus neomorphically calcitized rudists from $\sim 41 \mathrm{mbsf}$ in Hole $877 \mathrm{~A}$ are within analytical error of each other (Table 1 and Fig. 4). These data suggest that neomorphic calcitization of these aragonitic rudists took place early in the diagenetic history of Wodejebato and in marine waters. Assuming that the strontium incorporated into the magnesian calcite cements was directly derived from seawater, the $\mathrm{Sr}$-isotope data are also consistent with the contention that cementation occurred almost immediately after sedimentation (Opdyke et al., this volume). Elsewhere in Hole 877 A, marine cements are low magnesian calcite (Opdyke et al, this volume). ${ }^{87} \mathrm{Sr} /{ }^{86} \mathrm{Sr}$ results for low magnesian calcite cements fall into two groups: (1) those (generally between $\sim 20$ and $80 \mathrm{mbsf}$ ) having ${ }^{87} \mathrm{Sr} /{ }^{86} \mathrm{Sr}$ measurements indistinguishable from the magnesian calcite cements, and (2) those $(\sim 0-50$ mbsf) having ${ }^{87} \mathrm{Sr} /{ }^{86} \mathrm{Sr}$ measurements that are significantly more radiogenic than the magnesian calcite cements. Some of the cements in this first group of low magnesium calcite cements are known to have precipitated in pores resulting from the selective dissolution of aragonite (Opdyke et al., this volume). These data suggest that shallow marine waters of Maastrichtian age may have been undersaturated with respect to aragonite. If this interpretation is confirmed, support would be lent to the hypothesis of a "greenhouse, calcite sea" in the Late Cretaceous (Sandberg, 1983; Opdyke and Wilson, 1993). Most of the low magnesian calcite cements in the second group are known to have precipitated in pores resulting from the selective dissolution of aragonite. These cements plus a number of cemented skeletal grainstones having radiogenic ${ }^{87} \mathrm{Sr} /{ }^{86} \mathrm{Sr}$ measurements $(>0.70790 \approx$ $32-18 \mathrm{Ma})$, also have high $\delta^{18} \mathrm{O}(\sim-1.0$; Opdyke et al., this volume).

Given the current published data and making the controversial but conservative (for these purposes) assumption that a short-term rapid increase in ${ }^{87} \mathrm{Sr} /{ }^{86} \mathrm{Sr}$ occurred around the Cretaceous/Tertiary boundary, ${ }^{87} \mathrm{Sr} /{ }^{86} \mathrm{Sr}=0.70790$ is a reasonable estimate of the upper limit of the ${ }^{87} \mathrm{Sr} /{ }^{86} \mathrm{Sr}$ value for Maastrichtian through Eocene seawater (Koepnick et al., 1985, 1988; Hess et al., 1986; Macdougall, 1988; Martin and Macdougall, 1991; Nelson et al., 1991; Denison et al., 1993). Therefore, the only reasonable source of ${ }^{87} \mathrm{Sr}$ for these midoceanic carbonates is "younger" seawater (Fig. 1). Consequently, these data suggest that the Cretaceous carbonate platform at Wodejebato was at least partly cemented long after the atoll had drowned and become a guyot, from pore fluids heavily influenced by Neogene seawater. By this time, Wodejebato would not only have become a guyot but would also have sunk to considerable depths. Therefore, the ${ }^{87} \mathrm{Sr} /{ }^{86} \mathrm{Sr}$ data strongly support the conclusion that diagenesis in Hole $877 \mathrm{~A}$ was heavily influenced by platform subsidence into progressively deeper, cooler and presumably lower $\mathrm{CaCO}_{3}$-saturated marine waters (Opdyke et al., this volume). These data also serve to emphasize that (1) geochemical measurements conducted on bulk-rock samples have the potential to be very misleading because of the danger of mixing phases with radically different chemistries, and (2) regardless of when cementation of Wodejebato shallow-water carbonates began, this process continued well into the Neogene.

Although coverage in Hole $871 \mathrm{C}$ is poorer than in Hole $877 \mathrm{~A}$, the ${ }^{87} \mathrm{Sr} /{ }^{86} \mathrm{Sr}$ data suggest that Paleocene sediments in the center of Limalok Guyot may have also undergone significant diagenesis in progressively younger, deeper marine waters. These data also suggest that this style of diagenesis may occur preferentially at the base of these carbonate platforms (Table 1 and Figs. 2-3). If these suggestions are confirmed, they may support models involving large-scale seawater convection driven by a geothermal gradient from the volcanic pedestal (e.g., Saller, 1984, 1986; Aharon et al., 1987; Swart et al., 1987; Vahrenkamp et al., 1988; Saller and Koepnick, 1990).

\section{Seawater-Basalt Interaction}

Although the strontium-isotope systematics of hydrothermal fluids $\left(>300^{\circ} \mathrm{C}\right)$ venting along the axes of mid-ocean ridges are relatively well understood (e.g., Michard et al., 1984; Von Damm et al., 1985), documentation of the chemistry of diffuse, low-temperature, 
off-ridge flow (with crustal ages up to and exceeding $70 \mathrm{Ma}$ ) is extremely poor (Hess et al., 1991). Hence, considerable uncertainty exists as to the degree of interaction between seawater and basalt over the range of temperatures characteristic of oceanic crust before it is sealed to seawater alteration.

Geochemical analysis of microsampled vein/vesicle solid phases from the rocks from Leg 144 provides a useful means of constraining the timing and mode of fluid flow within and chemical exchange with the volcanic pedestal at the base of Pacific guyots.

Three sequential modes of low-temperature mineral formation are thought to occur in oceanic crust (Staudigel et al., 1986): palagonite followed by smectites followed by carbonates. Most vein carbonates occurring within the upper $500 \mathrm{~m}$ of normal oceanic crust are thought to form from nearly pure seawater (e.g., Staudigel et al., 198I; Staudigel and Hart, 1985). Therefore, the isotopic composition of carbonates provides important constraints on the temperature (by way of $\delta^{18} \mathrm{O}$ ) and age (by way of ${ }^{87} \mathrm{Sr} /{ }^{86} \mathrm{Sr}$ ) of basalt alteration (e.g., Hart and Staudigel, 1978, 1982; Burns et al., 1992). Thus, the assumption, as far as Sr isotopes are concerned, is that the timing of alteration may be obtained simply by comparing measured ${ }^{87} \mathrm{Sr} /{ }^{86} \mathrm{Sr}$ ratios of vein calcites with the reference ${ }^{87} \mathrm{Sr} /{ }^{86} \mathrm{Sr}$ curve for seawater (Fig. 1).

The ${ }^{87} \mathrm{Sr} /{ }^{86} \mathrm{Sr}$ results for Leg 144 vein and vesicle calcites summarized above and shown in Figures 2-6 fall into three groups:

1. The uppermost samples (i.e., closest to the basalt/sediment interface) from Holes $872 \mathrm{~B}$ and $878 \mathrm{~A}$ yield $\mathrm{Sr}$-isotope ages that appear to approximate the pedestal age. At Lo-En Guyot (Hole 872B), the uppermost vein calcite gives an age of $\sim 75 \mathrm{Ma}$. Similarly, at MIT Guyot (Hole 878A), $\mathrm{Sr}$ in the uppermost vein calcite is the most radiogenic and gives a Cretaceous age, similar to that of the youngest overlying shallow-water carbonates. These $\mathrm{Sr}$-isotope data suggest that convection of seawater through the volcanic pedestal of these guyots extended to the timing of initiation of carbonate platform sedimentation.

2. Many samples from Holes $872 \mathrm{~B}, 877 \mathrm{~A}, 878 \mathrm{~A}$, and $879 \mathrm{~A}$ have Sr-isotope ratios $(\sim 0.705-0.707)$ that indicate deposition from seawater with some basaltic component. This second group is most likely explained by mixing between seawater and high-temperature fluids.

3. Perhaps the most important observation is that a significant number of samples have ${ }^{87} \mathrm{Sr} /{ }^{86} \mathrm{Sr}$ ratios approximating that of upper mantle $\mathrm{Sr}(\sim 0.703)$. Such a situation occurs for some or all samples from Hole 871C (Limalok Guyot), Hole 872B (Lo-En Guyot) and Hole 878A (MIT Guyot). In such circumstances, it is impossible to use the ${ }^{87} \mathrm{Sr} /{ }^{86} \mathrm{Sr}$ measurements to constrain the timing of crust alteration. With one exception, we are unaware of any previous data on vein carbonate from basalts that show this mantle $\mathrm{Sr}$ signature. Staudigel and Hart (1985) showed that vein carbonate from Hole 504B had ${ }^{87} \mathrm{Sr} /{ }^{86} \mathrm{Sr}$ ratios of $\sim 0.7041$, equivalent to a $\sim 80 \%$ basalt $\mathrm{Sr}$ component. In the case of the present study, ${ }^{87} \mathrm{Sr} /{ }^{86} \mathrm{Sr}$ ratios as low as 0.7035 were found, equivalent to almost $100 \%$ basaltic $\mathrm{Sr}$. The results may indicate that the volcanic pedestals of these guyots have been affected by high-temperature fluids (allowing exchange of $\mathrm{Sr}$ between seawater and basalt), but this would seem at variance with the record of such fluids being preserved in carbonate. A second possibility is of a lowtemperature, upwelling zone in the seamounts where there has been total exchange with upper mantle $\mathrm{Sr}$ (H. Staudigel, pers. comm., 1993). Evaluating the formation temperatures of the carbonate using $\delta^{18} \mathrm{O}$ will be crucial to this argument. Staudigel and Hart (1985) suggested that basalt alteration at Hole 504B provided sufficient $\mathrm{Ca}^{2+}$ to circulating fluids to permit $\mathrm{CaCO}_{3}$ precipitation. The carbonates from Hole 504B showed extremely low $\mathrm{Sr}$ contents, which is consistent with this suggestion, and it will be important also to consider this in future work.

\section{SUMMARY}

Strontium-isotope stratigraphy confirms that Wodejebato drowned in the Maastrichtian (the best age estimates are for well-preserved ara- gonitic rudists and magnesian carbonate cements, plus neomorphically calcitized aragonitic rudists; i.e., $\sim 41 \mathrm{~m} \approx 70.5 \mathrm{Ma}$ ). Deficiencies in the ${ }^{87} \mathrm{Sr}{ }^{\beta 6} \mathrm{Sr}$ seawater curve for the Aptian/Albian do not allow precise estimation of the timing of cessation of shallow-water carbonate deposition on MIT and Tayuko-Daisan guyots. However, the data presented may suggest that Tayuko-Daisan drowned before MIT Guyot as predicted if drowning occurred as the platforms approached the equator on the northward-moving Pacific Plate (Erba et al., 1993).

This paper serves to underline the need to improve both the ${ }^{87} \mathrm{Sr} /{ }^{86} \mathrm{Sr}$ seawater curve for the Aptian/Albian and ${ }^{87} \mathrm{Sr} /{ }^{86} \mathrm{Sr}$ coverage in MIT and Tayuko-Daisan guyots.

In the absence of information on the chemistry of pore/borehole fluids from deep within cemented shallow-water carbonate platforms, the timing and mode of fluid flow and diagenesis within these features are best constrained by geochemical analysis of microsampled solids. ${ }^{87} \mathrm{Sr} /{ }^{86} \mathrm{Sr}$ determinations on bulk-rock samples have the potential to be very misleading because of the danger of mixing phases with radically different chemistries.

${ }^{87} \mathrm{Sr} /{ }^{86} \mathrm{Sr}$ data presented serve to emphasize that (1) Late Cretaceous seawater may well have been less saturated with respect to $\mathrm{CaCO}_{3}$ than it is today; (2) the diagenetic histories of Limalok and Wodejebato guyots were heavily influenced by platform subsidence into progressively deeper, presumably cooler, and less $\mathrm{CaCO}_{3}$-saturated marine waters; and (3) circulation within these platforms may have been driven by a geothermal gradient from the underlying volcanic pedestals.

${ }^{87} \mathrm{Sr} /{ }^{86} \mathrm{Sr}$ measurements conducted on vein/vesicle carbonates precipitated in the volcanic pedestal at the base of Pacific guyots suggest that (1) volcanic pedestals upon which atolls are born may be the sites of active circulation of seawater at the time of initiation of shallowwater carbonate deposition, and (2) the existing model for seawater alteration of the oceanic crust may require reevaluation (Staudigel et al., 1981).

\section{ACKNOWLEDGMENTS}

We are grateful to the staff of the ODP, both on and off JOIDES Resolution for their support of this work. We also thank the shipboard scientific party of Leg 144, Ann Williams and Mervyn Greaves at Cambridge for invaluable laboratory assistance, K.C. Lohmann and Lynn Walter at Michigan for generosity in allowing us to use their facilities, the staff at UK ODP for their continued support of our involvement in Leg 144, and John McArthur and Hugh Jenkyns for graciously making preprints available. We thank Tony Dickson and Nick Shackleton for help with this project and Judy McKenzie and Art Saller for constructive reviews. This work was supported by NERC Grant No. GR3/7828 (H.E.), a NERC Research Studentship No. GT4/91/AAPS/8 (P.A.W.), and USSSP Grant No. 144-20751B (B.N.O). Cambridge Earth Sciences Series, Contribution No. 3626.

\section{REFERENCES}

Aharon P., Goldstein, S.L., Wheeler, C.W., and Jacobson, G., 1993. Sea-level in the South Pacific linked with the Messinian salinity crisis. Geology, 21:771-775

Aharon, P., Socki, R.A., and Chan, L., 1987. Dolomitization of atolls by seawater convection flow: test of a hypothesis at Niue, South Pacific. $J$. Geol., 95:187-203.

Berggren, W.A., Kent, D.V., and Flynn, J.J., 1985a. Jurassic to Paleogene: Part 2. Paleogene geochronology and chronostratigraphy. In Snelling, N.J. (Ed.), The Chronology of the Geological Record. Geol. Soc. London Mem., 10:141-195.

Berggren, W.A., Kent, D.V., Flynn, J.J., and van Couvering, J., 1985b. Neogene geochronology and chronostratigraphy. In Snelling, N.J. (Ed.), The Chronology of the Geological Record. Geol. Soc. London Mem., 10:211-250.

- Abbreviations for names of organizations and publications in ODP reference lists follow the style given in Chemical Abstracts Service Source Index (published by American Chemical Society). 
Burke, W.H., Denison, R.E., Hetherington, E.A., Koepnick, R.B., Nelson. H.F., and Otto, J.B., 1982. Variation of seawater ${ }^{87} \mathrm{Sr} /{ }^{86} \mathrm{Sr}$ throughout Phanerozoic time. Geology, 10:516-519.

Burnett, J.A., Hancock, J.M., Kennedy, W.J., and Lord, A.R., 1992. Macrofossil, planktonic foraminiferal and nannofossil zonation at the Campanian/ Maastrichtian boundary. Newsl. Stratigr., 27:157-172.

Burns, S.J., Baker, P.A., and Elderfield, H., 1992. Timing of carbonate mineral precipitation and fluid flow in sea-floor basalts, northwest Indian Ocean. Geology, 20:255-258.

Denison, R.E., Koepnick, R.B., Fletcher, A., Dahl, D.A., and Baker, M.C., 1993. Reevaluation of Early Oligocene, Eocene, and Paleocene seawater strontium isotope ratios using outcrop samples from the U.S. Gulf Coast. Paleoceanography, 8:101-126.

DePaolo, D.J., 1986. Detailed record of the Neogene $\mathrm{Sr}$ isotopic evolution of seawater from DSDP Site 590B. Geology, 14:103-106.

Elderfield, H., 1986. Strontium isotope stratigraphy. Palaeogeogr., Palaeoclimatol., Palaeoecol., 57:71-90.

Elderfield, H., Swart, P.K., McKenzie, J.A., and Williams, A., 1993. The strontium isotopic composition of pore waters from Leg 133: northeast Australian margin. In McKenzie, J.A., Davies, P.J., Palmer-Julson, A., et al., Proc. ODP, Sci. Results, 133: College Station, TX (Ocean Drilling Program), 473-480.

Erba, E., Bergersen, D.D., Larson, R.L., Lincoln, J.M., Nakanishi, M., and ODP Leg 144 Scientific Party, 1993. Paleolatitude and vertical subsidence histories of ODP Leg 144 guyots. Eos (Suppl.), 74:353.

Harland, W.B., Armstrong, R.L., Cox, A.V., Craig, L.E., Smith, A.G., and Smith, D.G., 1990. A Geologic Time Scale 1989: Cambridge (Cambridge Univ. Press).

Hart, S.R., and Staudigel, H., 1978. Ocean crust: age of hydrothermal alteration. Geophys. Res. Lett., 5:1009-1012.

1982. The control of alkalies and uranium in sea water by ocean crust alteration. Earth Planet. Sci. Lett., 58:202-212.

Hess, J., Bencier, M.L., and Schilling, J.G., 1986. Evolution of the ratio of strontium-87 to strontium-86 in seawater from Cretaceous to Present. Science, 231:979-984

_ 1991. Assessing seawater/basalt exchange of strontium isotopes in hydrothermal processes on the flanks of mid-ocean ridges. Earth Planet. Sci. Lett., 103:133-142.

Hess, J., Stott, L.D., Bender, M.L., Kennett, J.P., and Schilling, J.-G., 1989. The Oligocene marine microfossil record: age assessments using strontium isotopes. Paleoceanography, 4:655-679.

Hodell, D.A., Mead, G.A., and Mueller, P.A., 1990. Variation in the strontium isotopic composition of seawater ( $8 \mathrm{Ma}$ to present): implications for chemical weathering rates and dissolved fluxes to the oceans. Chem. Geol. (Isotope Geosci. Sect.), 80:291-307.

Hodell, D.A., Mueller, P.A., and Garrido, J.R., 1991. Variations in the strontium isotopic composition of seawater during the Neogene. Geology, 19:24-27.

Hodell, D.A., Mueller, P.A., McKenzie, J.A., and Mead, G.A., 1989. Strontium isotope stratigraphy and geochemistry of the late Neogene ocean. Earth Planet. Sci. Lett., 92:165-178.

Jenkyns, H.C., Paull, C.K., Cummins, D.I., and Fullagar, P.D., 1995. Strontium-isotope stratigraphy of Lower Cretaceous atoll carbonates in the mid-Pacific Mountains. In Winterer, E.L., Sager, W.W., Firth, J.V., and Sinton, J.M. (Eds.), Proc. ODP, Sci Results, 143: College Station, TX (Ocean Drilling Program), 91-99.

Jones, C.E., 1992. The strontium isotopic composition of Jurassic and Early Cretaceous seawater [Ph.D. dissert.]. Oxford Univ.

Jones, C.E., Jenkyns, H.C., Coe, A.L., and Hesselbo, S.P., 1994. Strontium isotope variations in Jurassic and Cretaceous seawater. Geochem. Cosmochim. Acta, 58:3061-3074

Koepnick, R.B., Burke, W.H., Denison, R.E., Hetherington, E.A., Nelson, H.F., Otto, J.B., and Waite, L.E., 1985. Construction of the seawater ${ }^{87} \mathrm{Sr} /{ }^{86} \mathrm{Sr}$ curve for the Cenozoic and Cretaceous: supporting data. Chem. Geol. (Isotope Geosci. Sect.), 58:55-81.

Koepnick, R.B., Denison, R.E., Burke, W.H., Hetherington, E.A., and Dahl, D.A., 1990. Construction of the Triassic and Jurassic portion of the Phanerozoic curve of seawater ${ }^{87} \mathrm{Sr} /{ }^{86} \mathrm{Sr}$. Chem. Geol. (Isotope Geosci. Sect.), 80:327-349.

Koepnick, R.B., Denison, R.E., and Dahl, D.A., 1988. The Cenozoic seawater ${ }^{87} \mathrm{Sr} /{ }^{86} \mathrm{Sr}$ curve: data review and implications for correlation of marine strata. Paleoceanography, 3:743-756.
Ladd, H.S., and Schlanger, S.O., 1960. Drilling operation on Enewetak Atoll. Geol. Surv. Prof. Pap. U.S., 260Y:863-905.

Lincoln, J.M., and Schlanger, S.O., 1987. Miocene sea level falls related to the geological history of Midway Atoll. Geology, 15:454-457.

-1991 . Atoll stratigraphy as a record of sea level change: problems and prospects. J. Geophys. Res., 96:6727-6752.

Ludwig, K.R., Halley, R.B., Simmons, K.R., and Peterman Z.E., 1988. Strontium-isotope stratigraphy of Enewetak Atoll. Geology, 16:173-177.

Macdougall, J.D., 1988. Seawater strontium isotopes, acid rain, and the Cretaceous-Tertiary boundary. Science, 239:485-487.

Major, R.P., and Matthews, R.K., 1983. Isotopic composition of bank margin carbonates on Midway Atoll: amplitude constraint on post-early Miocene eustacy. Geology, 11:335-338.

Martin, E.E., and Macdougall, J.D., 1991. Seawater Sr isotopes at the Cretaceous/Tertiary boundary. Earth Planet. Sci. Lett., 104:166-180.

McArthur, J.M., Kennedy, W.J., Chen, M., Thirlwall, M.F., and Gale, A.S., 1994. Strontium isotope stratigraphy for the Late Cretaceous: direct numerical age calibration of the $\mathrm{Sr}=1 \mathrm{E}$ isotope curve for the U.S. Western Interior Seaway. Palaeogeogr., Palaeoclimatol., Palaeoecol., 108:95-119.

McArthur, J.M., Kennedy, W.J., Gale, A.S., Thirlwall, M.F., Chen, M., Burnett, J., and Hancock, J.M., 1993a. Strontium isotope stratigraphy in the Late Cretaceous: intercontinental correlation of the Campanian/Maastrichtian boundary. In Hailwood, E., and Kidd, R. (Eds.), High Resolution Stratigraphy. Geol. Soc. Spec. Publ. London, 70:195-209.

McArthur, J.M., Kennedy, W.J., Gale, A.S., Thirlwall, M.F., Chen, M., and Hancock, J.M., 1992. Strontium isotope stratigraphy in the Late Cretaceous intercontinental correlation of the Campanian/Maastrichtian boundary. Terra Nova, 4:385-393.

McArthur, J.M., Thirlwall, M.F., Chen, M., Gale, A.S., and Kennedy, W.J., 1993b. Strontium isotope stratigraphy in the Late Cretaceous: numerical calibration of the $\mathrm{Sr}$ isotope curve and intercontinental correlation for the Campanian. Paleoceanography, 8:859-873.

McKenzie, J.A., Hodell, D.A., Mueller, P.A., and Mueller, D.W., 1988. Application of strontium isotopes to late Miocene-early Pliocene stratigraphy. Geology, 16:1022-1025.

McKenzie, J.A., Isern, A., Elderfield, H., Williams, A., and Swart, P., 1993. Strontium isotope dating of paleoceanographic, lithologic, and dolomitization events on the northeastern Australian margin, Leg 133. In McKenzie, J.A., Davies, P.J., Palmer-Julson, A., et al., Proc. ODP, Sci. Results, 133: College Station, TX (Ocean Drilling Program), 489-498.

Michard, G., Albarede, F., Michard, A., Minster, J.F., Charlou, J.L., and Tan, N., 1984. Chemistry of solutions from the $13^{\circ} \mathrm{N}$ East Pacific Rise hydrothermal site. Earth Planet. Sci. Lett., 67:297-307.

Miller, K.G., Feigenson, M.D., Kent, D.V., and Olsson, R.K., 1988. Upper Eocene to Oligocene isotope $\left({ }^{87} \mathrm{Sr} /{ }^{86} \mathrm{Sr}, \delta^{18} \mathrm{O}, \delta^{13} \mathrm{C}\right)$ standard section, Deep Sea Drilling Project Site 522. Paleoceanography, 3:223-233.

Nelson, B.K., MacLeod, G.K., and Ward, P.D., 1991. Rapid change in strontium isotopic composition of sea water before the Cretaceous/Tertiary boundary. Nature, 351:644-647.

Obradovich, J.D., 1993. A Cretaceous time scale. In Caldwell, W.G.E., and Kauffman, E.G. (Eds.), Cretaceous Evolution of the Western Interior Basin of North America. Spec. Pap. Geol. Assoc. Can.

Ohde, S., and Elderfield, H., 1992. Strontium isotope stratigraphy of KitaDaito-Jima Atoll, North Philippine Sea: implications for Neogene sea-level change and tectonic history. Earth Planet. Sci. Lett., 113:473-486.

Opdyke, B.N., and Wilson, P.A., 1993. Geochemical constraints on late Cretaceous tropical surface sea water and chemistry based on relatively pristine carbonate from Leg 144, Site 877A. Wodejebato Guyot. Eos (Suppl.), 353

Oslick, J.S., Miller, K.G., and Feigenson, M.D., 1994. Oligocene-Miocene strontium isotopes: stratigraphic revisions and correlations to an inferred glacioeustatic record. Paleoceanography, 9:427-423.

Paull, C.K., Fullagar, P.D., Bralower, T.J., and Röhl, U., 1995. Seawater ventilation of mid-Pacific guyots drilled during Leg 143. In Winterer, E.L., Sager, W.W., Firth, J.V., and Sinton, J.M. (Eds.), Proc. ODP, Sci. Results, 143: College Station, TX (Ocean Drilling Program), 231-241.

Premoli Silva, I., Haggerty, J., Rack, F., et al., 1993. Proc. ODP, Init. Repts., 144: College Station, TX (Ocean Drilling Program).

Quinn, T.M., Lohmann, K.C., and Halliday, A.N., 1991. Sr isotopic variation in shallow water carbonate sequences: stratigraphic, chronostratigraphic, and eustatic implications of the record at Enewetak Atoll. Paleoceanography, 6:371-385. 
Quinn, T.M., and Matthews, R.K., 1990. Post-Miocene diagenetic and eustatic history of Enewetak Atoll: model and data comparison. Geology, 18:942945.

Saller, A.H., 1984. Petrologic and geochemical constraints on the origin of subsurface dolomite, Enewetak Atoll: an example of dolomitization by normal seawater. Geology, 12:217-220.

1986. Radiaxial calcite in lower Miocene strata, subsurface Enewetak Atoll. J. Sediment. Petrol., 56:743-762.

Saller, A.H., and Koepnick, R.B., 1990. Eocene to early Miocene growth of Enewetak Atoll: insight from strontium isotope data. Geol. Soc. Am. Bull., 102:381-390.

Sandberg, P.A., 1983. An oscillating trend in Phanerozoic non-skeletal carbonate mineralogy. Nature, 305:19-22.

Simms, M., 1984. Dolomitization by groundwater-flow systems in carbonate platforms. Trans. Gulf Coast Assoc. Geol. Soc., 34:411-420.

Staudigel, H., and Hart, S.R., 1985. Dating of ocean crust hydrothermal alteration: strontium isotope ratios from Hole 504B carbonates and a reinterpretation of Sr isotope data from Deep Sea Drilling Project Sites 105, 332, 417 , and 418. In Anderson, R.N., Honnorez, J., Becker, K., et al., Init. Repts. DSDP, 83: Washington (U.S. Govt. Printing Office), 297-303.

Staudigel, H., Hart, S.R., and Richardson, S.H., 1981. Alteration of the oceanic crust: processes and timing. Earth Planet. Sci. Lett., 52:311-327.

Staudigel, H., Kastner, M., and Sturz, A., 1986. $\delta^{18} \mathrm{O}$ and ${ }^{87} \mathrm{Sr} /{ }^{86} \mathrm{Sr}$ of calcites from the basaltic basement of Deep Sea Drilling Project Site 597: timing and temperature of alteration. $n$ Leinen, M., Rea, D.K., et al., Init. Repts. DSDP, 92: Washington (U.S. Govt. Printing Office), 499-503.

Swart, P.K., and Guzikowski, M., 1988. Interstitial-water chemistry and diagenesis of periplatform sediments from the Bahamas, ODP Leg 101. In
Austin, J.A., Jr., Schlager, W., Palmer, A.A., et al., Proc. ODP, Sci. Results, 101: College Station, TX (Ocean Drilling Program), 363-380.

Swart, P.K., Ruiz, J., and Holmes, C.W., 1987. Use of strontium isotopes to constrain the timing and mode of dolomitization of upper Cenozoic sediments in a core from San Salvador, Bahamas. Geology, 15:262-265.

Vahrenkamp, V.C., Swart, P.K., and Ruiz, J., 1988. Constraints and interpretation of ${ }^{87} \mathrm{Sr} /{ }^{86} \mathrm{Sr}$ ratios in Cenozoic dolomites. Geophys. Res. Lett., $15: 385-388$.

Von Damm, K.L., Edmond, J.M., Grant, B., Measures, C.I., Walden, B., and Weiss, R.F., 1985. Chemistry of submarine hydrothermal solutions at $21^{\circ}$ N, East Pacific Rise. Geochim. Cosmochim. Acta, 49:2197-2220.

Wheeler, C.W., and Aharon, P., 1991. Mid-oceanic carbonate platforms as oceanic dipsticks: examples from the Pacific. Coral Reefs, 10:101-114.

Whitaker, F.F., and Smart, P.L., 1990. Active circulation of saline ground waters in carbonate platforms: evidence from the Great Bahama Bank. Geology, 18:200-203.

Winterer, E.L., van Waasbergen, R., Stuart, S., et al., 1993. Topographic effects of erosion and differential compaction of Lower Cretaceous platform limestone, marlstone, and claystone over buried volcanic topography, Mid-Pacific Mts. Eos (Suppl.), 354.

Date of initial receipt: 31 January 1994

Date of acceptance: 15 September 1994

Ms 144SR-055 